\title{
WE BOTH EAT RICE, BUT THAT'S ABOUT IT: KOREAN AND LATINO RELATIONS IN A MULTI-ETHNIC CITY
}

\section{Chong-suk Han \\ Temple University}

\section{INTRODUCTION}

On any given day, in any given restaurant in Koreatown, countless orders are taken, meals are served, tables are cleared, dishes are washed, and checks are paid. Down the street at a corner convenience store, shelves are stocked, beverages are placed into large refrigerators, and purchases are rung up. Even to the most casual observer, it becomes obvious that Korean workers take the orders and collect the money while Latino workers replenish the shelves, clear the tables, and wash the dishes.

While the routine activity in a restaurant or a convenience store may not seem extraordinary, what is significant is the creation of a common environment where different ethnic groups come together to perform various tasks. These locations, which Louis Lamphere calls "mediating institutions" - including workplaces, schools, apartment houses, community organizations, and government agencies - bring ethnic groups, who would otherwise have only limited contact, together for daily interaction (Lamphere et al. 1994). Because these institutions are often the only places where such ethnic groups have daily contact with each other, ethnic prejudices and misconceptions created within the confines 
of these specific interactions develop into widespread belief systems (Lee 2002). That is, when members of one ethnic group form opinions of another ethnic group in these limited settings, they are likely to disseminate this information through their own ethnic networks until these experiences come to be understood as the stereotypical "norm" in interactions with the other group. As such, these interactions have profound implications for Korean/Latino conflict given the structure of certain "mediating institutions" that are likely to bring these groups into daily contact.

In this paper, I argue that the structure of Korean American owned stores relegates Latinos to more difficult and less lucrative positions and Korean Americans to more privileged positions. By doing so, it creates a system of oppression that favors Koreans over Latinos. I argue that such structural arrangements in L.A.'s Koreatown contribute to ethnic antagonism between Korean storeowners and Latino workers. I hypothesize that it is the formation of these specific "mediating institutions," in the form of split labor markets, which is an important factor in shaping the nature of ethnic conflict between Koreans and Latinos.

\section{THEORETICAL IMPLICATIONS}

In 1989, only three years before the Los Angeles uprising, Cheng and Espiritu hypothesized that Latinos and Koreans share an immigrant ideology. Immigrants believe that America is still the land of opportunity and are often willing to work extra hard hours because they hold on to the possibility that they can rise within the established system through perseverance and hard work (Cheng and Espiritu 1989). Their findings, based on an exhaustive search of Spanish language newspapers, suggested that there were no overt racial tensions between Korean Americans and Latinos. Their findings were also mirrored by "real life" events. While blacks in urban areas were actively picketing Korean owned stores in black communities, there was little overt conflict among Latinos and Korean American store owners, even in heavily Latino neighborhoods.

Given the lack of media and academic discussions about Latino and Korean conflict, it isn't surprising that when the Los Angeles uprising erupted in April of 1992, academic and popular literature 
tended to interpret it as a "black riot." One article attempted to explain the urban uprising by equating events in 1992 with the Watts Riots of 1965 (Chang 1993). The urban uprising became another "black riot" in most media accounts. In this scheme, Korean American merchants became modern-day Jewish merchants while the rioters were still, simply, black (Chang 1993).

However, even before the burning and looting were over, it became obvious that the largest group affected by the damage caused were Korean American merchants who made a living in, or on the periphery of, largely poor Latino neighborhoods. Yet the fact that Latinos constituted a majority of riot participants (HayesBautista et. al. 1993; Park 1995; Pastor 1993), and that the riots were heavily concentrated in largely Latino neighborhoods, was downplayed in both the press and the scholarly literature.

In addition, Latinos constituted 50.6 percent of the 5,633 people arrested while African Americans constituted only 36.2 percent. Given that the most heavily affected areas had a 49 percent Latino residential population, it may not be surprising that nearly 51 percent of the arrested were Latino. However, among those arrested, over 65 percent of Latinos were arrested for suspicion of looting and illegal actions rather than simple curfew violations while only 55 percent of African Americans were arrested for riot related activities. Overall, a larger percentage of those arrested for more serious illegal activities were Latino than would be expected even given their greater numbers in the community. Nonetheless, this lack of coverage regarding the role that Latinos and Korean Americans played during the unrest is not surprising given the long history of looking at race along a black/white paradigm (Alcoff 2003; Park and Park 1999).

Surely, ethnic tensions arising out of competition of limited resources, historically based inequalities, and scapegoating play a major part in this particular ethnic conflict (Bergeson and Herman 1998; Light et. al. 1993). However, these explanations rely on several points that are more relevant to Korean/Black relations than to Korean/Latino relations.

According to the middleman minority theory, certain racial or ethnic groups come to play the intermediate role between the dominant and subordinate classes, particularly in societies 
characterized by large class divisions. In these societies, the middlemen groups come to occupy the unenviable position of providinggoods produced by the dominant group to the subordinate group by acting as merchants in low-income neighborhoods. Within this arrangement, conflict arises because the customers served by middleman merchants view these merchants as "moving in" on their area and behaving in an economically unscrupulous manner (Bonacich 1973). In fact, several scholars have shown that this seems to be at least partly to blame for black/Korean conflict (Kim 2000; Min 1996; Min and Kolodny 1999; Yoon 1997). However, middleman minority theory assumes that certain groups are targeted because they are viewed as outsiders (Light et. al 1993). While we might assume a high level of black identification with their residential surroundings, this seems a problematic assumption for Latinos. Latinos residing in once historically black neighborhoods are also a relatively "new" group who often view their immediate place of residence as temporary and may not claim nativity (Skerry 1993). In addition, the majority of Latinos do not see Korean American merchants as being "outsiders" who act as a predatory element in their community, a very pivotal point in middleman theory (Cheng and Espiritu 1989; Yoon 1998).

The prevalence of riot-related damage occurring in South Central gives credence to the explanation that the riot was largely a backlash on the part of local blacks against recent immigrants in largely black neighborhoods (Bergeson 1998). In fact, while Korean-owned stores were burned, the overwhelming majority of black-owned businesses escaped unscathed (Lee 2002). However, this argument rests on the assumption that heavily affected areas are in a state of population shift where the group originally in the majority see itself as being threatened by recent immigrants who are seen as taking their jobs and housing. As noted earlier, this analysis suggests that heavy riot activity occurs where there is no significant majority.

However, Koreatown, the second most affected area, with less than 5 percent black population and nearly 70 percent Latino population, clearly does not fit this model (Pastor 1993). This contradiction has led at least one scholar to dismiss the riot activity in Koreatown as a "bread basket riot" where high rates of 
poverty accounted for the rioting (Bergeson 1996). This assumes that Latinos in Koreatown were somehow more poverty stricken than Latinos in other areas of Los Angeles County where they did not riot. However:

In terms of community profiles revealed in the 1990 census, Latinos in South Central do not differ substantially from Latinos in neglected areas in the rest of the county, and both of these groups of Latinos differ only by matter of degrees from Latinos in [non affected] areas of the county, by virtue of being somewhat poorer and less educated. However, some key characteristics, such as high rates of family formation and labor force participation, are common to all Latinos. Thus, the key to Latino participation in the riots can not be sought only in the "objective conditions" in which Latinos live; if poverty alone caused riots, Latinos should have been looting nearly everywhere in the county (Hayes-Bautista et. al. 1993, 445).

While the Hayes-Buatista et. al. (1993) study singled out Latinos in South Central and not Koreatown, the argument made is that Latinos in all areas of Los Angeles County share similar economic backgrounds.

To distance themselves from Latino rioters, Latino leaders were quick to point out that Latinos in riot damaged areas were somehow different from other Latinos in Los Angeles, particularly East Los Angeles. They stated that Latino in the areas heavily affected by the uprising were largely Central American and were recent arrivals to the United States (Hayes-Bautista et. al. 1993). While Latinos in Koreatown were a more diverse group with 44 percent coming from Central America, Mexicans still account for 48 percent of the resident Latino population. More significantly, people of Mexican origin made up over 75 percent of Latino residents in South Central Los Angeles (Pastor 1993). While it may be that immigrants in Koreatown are more recent arrivals with 49 percent arriving after 1980 as opposed to the 25 percent arriving after 1980 in East Los Angeles, levels of non-citizenship for all residents in both areas appear less dramatically different at 
69.4 percent in Koreatown and 56.2 percent in East Los Angeles. In addition, the higher percentage of recent immigrants and noncitizenship in Koreatown may be due to recent immigrants from Korea as opposed to recent immigrants from Latin America (Kim and Wong 1977).

These findings have led some scholars to state that differences between the Latino population in East Los Angeles and Koreatown were minimal at best (Hayes-Bautista et. al. 1993). What then, accounts for the riot activity spreading into Koreatown and not East Los Angeles, both of which are in approximately equal distance from the riot epicenter of South Central Los Angeles? A possible explanation may come from the ethnic interactions common in Koreatown but not in other parts of Los Angeles where Latinos are a significant numeric majority.

While important to the analysis because of their class position within the affected neighborhoods, Koreans and their actual role ethnic conflicts is not the subject of much investigation. Nor, for that matter, are Asians and Latinos the topic of much scholarship about race (Park and Park 1999). If we assume that the only factor that led Korean owned stores being targeted was class, we might have seen a similar level of unrest in East Los Angeles where other groups own the economic outlets. A possible explanation may be that the pattern of riot activity in Koreatown was affected by the actions that Korean American merchants take in their daily interaction with the local population.

A hint of this comes from the fact that riot related damage was very different in Koreatown and South Central Los Angeles. While Korean owned stores in South Central Los Angeles were more likely to be burned, Korean owned stores in Koreatown were much more likely to be looted (Ong and Hee 1993; Light et. al. 1994). While an argument can be made that Koreatown businesses were more prone to be looted because of the type of goods that they sell, analysis of riot affected businesses in Koreatown and South Central show that all types of businesses were affected in both areas (Ong and Hee 1993). As such, the intent in black neighborhoods seems to have been eviction while the intent in largely Latino neighborhoods seems to have been redistribution. 
If we assume that differences between the Latino population in the riot affected areas and the non-affected areas were minimal at best (Hayes-Bautista et. al. 1993), why did Latinos in Koreatown participate in the riots while those in other parts of Los Angeles County did not? More importantly, why did Latinos participate in specific types of riot related activities but not others? I maintain that the activities surrounding the Los Angeles riot of 1992 hint at an underlying friction among Korean storeowners and Latino workers and residents.

This paper is an attempt to explain a possible source of Korean American and Latino conflict in Los Angeles. Drawing largely on ethnographic fieldwork in Koreatown, I place Koreans and Latinos in the context of a multi-ethnic city in order to address the theoretical implications of ethnic conflict, describe the relationship between Latinos and Korean Americans as they interact with each other in Korean owned workplaces, and analyze the nature of these relationships to locate possible factors that may contribute to the formation of ethnic antagonism between Latinos and Korean Americans.

\section{SPLIT LABOR MARKET}

The underlying theme of the split labor market theory is that ethnic antagonism develops in a labor market split along ethnic lines. While racial and cultural differences may foster the development of ethnic antagonism, the split labor market theory suggests that economic processes are more fundamental to the creation of ethnic antagonism (Bonacich 1972).

The formation of a split labor market depends on different ethnic groups, with different socio-economic backgrounds entering the same labor market at different rates of pay (Bonacich 1972). The specifics of the formation and existence of the split labor market in Koreatown and the exploitation faced by low-paid workers will be discussed later. However, it is important to note that the existence of a split labor market and the exploitation faced by low-paid workers has been documented in other Los Angeles industries such as the garment industry (Bonacich 1993). Much like businesses in Koreatown, the Los Angeles garment industry is characterized by Korean American bosses exploiting Latino 
workers (Bonacich 1993). While the operators of small enterprises may not be the actual oppressors who hold any real power over the general economic process, they are in control of employment and business practices in Koreatown. In addition, because the Latino workers are in daily contact with their Korean bosses, the Korean bosses are the only visible oppressors.

\section{METHODOLOGICAL ISSUES}

This paper is based on ethnographic fieldwork and interviews conducted between 1995 and 1996, and again in 2003, in Los Angeles. Exploiting existing networks, I sought out Korean American storeowners who owned small businesses within the most heavily affected areas during the 1992 Los Angeles uprising as outlined by the Pastor (1993). Using snowball sampling methods, I interviewed twelve Korean American storeowners and conducted ethnographic observations at their businesses. Among the stores, six were located in Koreatown, four in Central Avenue/South Park, and two in Vermont Square. The stores were all "mom and pop" operations with less than four paid employees. Three of the stores had no paid employees. The businesses included restaurants (four), liquor stores (seven), and one beauty supply store. These interviews were conducted in Konglish, a uniquely American language composed of English and Korean. Where answers were given in English, I transcribed and present them verbatim. Where answers were given in Korean, I translated them to the best of my ability. Four of these Korean American storeowners were interviewed again in 2003.

I met the first of five Latino informants while working as a food server at an Italian restaurant in Santa Monica. Through this initial contact, I earned the confidence of four other Latino workers who all worked for, or were currently working for, Korean employers. All of these interviews were conducted in English. Seven more informants provided shorter interviews which were conducted by a Spanish-speaking assistant. They were identified through her networks. These shorter interviews were used only to clarify and/or support themes found in the five longer interviews. Four of the short interview respondents had no prior experience working for Korean owned stores. However, all previously lived or were 
currently living in the areas identified by the Pastor (1993). These interviews, which were conducted in Spanish, were translated by the Spanish-speaking interviewer.

Rather than coding and counting frequencies, I examined the themes found within the narratives. I was interested in how Korean Americans and Latinos made sense of each other. As I examined these themes, I was particularly interested in how members of both of these groups constructed what it meant to be the "other." Particularly, I found that during their interactions, they actively formed ideas about each other and, through story telling and myth making, they solidified their constructions. More than simply "story-telling," I took these myths to be an important part in racial formation (Fine and Turner 2001).

\section{WORK PLACE STRUCTURE}

According to Bonacich, the development of a split labor market may entail the formation of a caste like system where one group is excludes members from another group from certain occupations with higher pay into occupations with lower pay (Bonacich 1972). This arrangement occurs when the in group cannot exclude the out group from the work force completely. In addition, in many incidences it is not in the employers' best interest to exclude certain groups.

Workers in the Korean American owned stores are arranged into a hierarchy based on "responsibility" and pay. Often times, these arrangements are made based on availability of labor or owner perception of competence. For example, one Korean informant explains why he does not hire Latino workers for some tasks in this way:

They have to handle money; they have to have a sense about money. They have to be responsible.... it's an education problem. They (Latinos) don't calculate things well. For instance, with Koreans, if someone buys two items, they can calculate how much something is. But(Latinos), they can't calculate these things. They constantly make mistakes so we can't use these people for that. 
This particular informant also stated that he uses Koreans for jobs like cashier and pays them at a higher rate. What is important to note is that if the workers were to be in the same position, they would be paid at different rates. Thus, while Korean store owners have excluded Latino workers from higher paying jobs, this may only be due to the employer's belief that if Koreans were to do the same jobs, they would require a higher rate of pay.

Within this system, rules and conceptions become rigid and vigilant which develops into an "elaborated battery of laws, customs and beliefs." (Bonacich 1972, 482) This, then, leads to the inability of the excluded groups to move into other positions due to the wide spread belief that they are somehow inadequate for certain positions.

Also, there seems to be a perceived oversupply of labor at the lower end of the scale. For example, according to another Korean informant:

There are always lots of (Latinos) coming looking for jobs. So I don't have to worry about busboys or dishwashers, there will always be others. If they don't like their job, then I can always find someone else.

This surplus labor market further reduces Latino power on the job and security of employment. Korean shop owners may prefer Koreans even for the low level jobs, but:

Koreans don't want to do these jobs (busboys, stock, and dishwasher). And even if they did, they wouldn't work for so little. So I hire (Latinos) to do these jobs and they seem okay. Also, Koreans were not meant to do these jobs. Latinos are stronger and are used to the hard work.

The last statement seems to indicate a wide consensus among Korean storeowners about the nature of the type of work Latinos can do. Korean storeowners generally believe that Latinos are somehow "suited" for manual labor based on their social and genetic make-up. One Korean storeowner tells me:

They're (Latinos) stronger than Koreans. So where 
strength is needed, they use Mexicans. Even since they were little, Mexicans have worked. But for Koreans, most people don't grow up doing hard work. They usually start working when they are about 25.... In Korea, if you're in the position to immigrate to America; it implies a certain social status, so they probably did not do hard labor. But for Mexicans, they are used to the hard work. So when a job requires labor and not any technical skill, Koreans tend to hire Mexicans.

In addition, Koreans tend to regard Latinos as "expendable" workers. This leads to the belief that they can also pay Latino workers less than Korean workers, place them into jobs which are lower in status and pay, and cut employment at their discretion. One Korean informant states:

I have not had any conflicts with my Latino workers, if I did, I could simply fire him and find someone else... There is a demand for these jobs and not enough positions, that's why their wages are so low... Koreans will not do these jobs and even if they did, I would have to pay them more.

The surplus labor market and the willingness for Latinos to provide the labor for these jobs reduce Latino power over their work schedules and give them little power over the security of their employment. This surplus Latino labor allows Korean storeowners to benefit but it is detrimental to Latino workers. By this I mean that Korean store owners not only have the benefit of hiring Latino workers at a lower rate of hourly pay, but offering odd and limited work schedules to further cut employment costs. According to one Korean American employer:

We use him for about four hours a day, seven days a week. He takes home about $\$ 600.00$ per month, but we pay him "under the table"... He seems to do all-right, I'm sure he doesn't have too many expenses...he lives with his sister and his rent is only about $\$ 250.00$ per month, so I'm sure he has 
enough.

The employment practices of the Korean American merchants rob Latino workers of key factors which they consider important to a good job. In a focus group study, Latinos indicated a good job offered job security, sense of responsibility, and upward mobility (Bobo et. al. 1995). Obviously, none of these things were offered to the Latino workers employed by my sample of Korean American merchants.

\section{IMMIGRANT STATUS}

The illegal status of an immigrant, as it is defined by the state, carries with it a certain level of discrimination and disabilities (Bonacich 1987). They lack the rights of citizens and are vulnerable to certain conditions which may be placed upon them by others. Therefore, it was not surprising that a significant reason that Korean American merchants viewed Latino workers as being "expendable" came from the merchant's perception of the workers legal status:

The one's without green cards are more docile. They don't complain as much and work harder. They have a sense of responsibility to the job and to the employer.

Later this same informant stated that:

The ones without green cards don't cause as much trouble because they don't want to get in trouble. They can't really complain to anyone because they will be sent back to Mexico. So it's more comfortable to have them as workers.

Yet another Korean merchant stated:

I prefer Mexican-born (workers). They don't know about American laws. They do as the owner tells them to do. The ones who are born here, they act up, make excuses for everything, and threaten to sue. Of course, I've never been sued, but I've heard that's what they do.

The use of undocumented immigrant labor is widespread in the Los Angeles garment industry (Bonacich, 1993); likewise they may be employed in other Korean businesses. The majority of the 
Korean informants stated that they had, at one time, employed an undocumented worker. In addition, several more stated that they were not sure of the status of the Latinos currently working for them.

Korean American merchants use the immigration status of their workers as a method of labor control. Korean American merchants feel that they do not need to offer full-time employment or benefits to their undocumented employees because they believe that there are no legal course of action that can be taken by their employees should they choose to discontinue the employment. This allows Korean American merchants to provide long hours of employment when needed and cut the hours of employment when it is no longer needed. Likewise, undocumented immigrants are often forced to take these jobs. According to a Latino worker:

Sometimes, they have no choice. They have to take the jobs because other people won't give them a job. The Koreans don't care, you can give them any fake papers and they usually don't check up on it. Usually, they pay in cash so it doesn't really matter.

Using the immigrants' illegal status provides Korean American merchants with two benefits. First, it guarantees submissive employment because the employees don't understand the legal course of action they could follow should they find themselves out of work. In addition, paying cash for labor allows Korean store-owners to pay workers less than the required minimum. In addition, they avoid paying taxes on their employees. Furthermore, unscrupulous Korean store-owners can take advantage of the situation. On Latino informant points this case out:

My brother always got less pay than he thought he deserved. He would check his hours and he would always get paid less. But the Korean lady, she said that she was taking taxes out of his pay, but he never got any papers, even after he quit.

Because the undocumented employees often do not file federal tax returns, it leaves the Korean storeowners the option of taking money out of the employees' pay and stating that the money is 
going for taxes without really paying them. As such, employers often deduct federal, state, social security, and local taxes without paying them to the government.

\section{WORKPLACE ANTAGONISM}

When asked to discuss Korean characteristics, Latinos tend to offer work related characteristics. For example, the Latino informants state that Koreas are discriminating in jobs, mean, cheap, demanding, dishonest, cheats, and angry. In addition, a common complaint against Koreans is that they do not pay timely, cheat you when they pay, show workers little respect, and expect long hard hours for relatively little pay. Although these complaints are work-place related, even Latinos who indicate that they have never worked for Koreans hold these same beliefs. This is interesting when we compare this to the type of complaints blacks expressed against Koreans. Most blacks tended to believe that Koreans are rude to customers, suspected all blacks as shop-lifters, would not give jobs to blacks, and would not extend credit to the credit worthy (Light et al. 1994). The significance of these differences is that Blacks viewed Korean store owners as "middlemen" who entered their neighborhoods and exploited their resources. Latinos on the other hand, seem to view Koreans as employers who exploit workers who are powerless against them. While the percentage of Latinos living in Koreatown who are working for Korean American owned stores could not be determined for this paper, casual observation indicates that Latinos make up the majority of the work force in Koreatown.

Although the Korean hiring practice may be partially due to their own economic limitations (Bonacich, 1987), it still places Latino workers in a situation of low income and low job security. While Koreans make these justifications for their hiring and paying practices, Latinos have a different perception of the workplace environment. A Latino informant sees the pay arrangements differently:

We agreed originally that I would be paid $\$ 50.00$ per day for 10 hours of work. I was supposed to come in at ten o'clock, work until three, take a break and come back by six and work another five 
hours. But, he always tries to cheat me. He wants me to stay longer and come back earlier from my break. One day, he sent me to clean his house and he didn't give me my break. He didn't pay me for these hours.

Interactions such as these lead Latino workers to view Korean store owners as being dishonest, cheap and demanding. In addition, these stories get circulated around the Latino community until they are accepted as "truths".

In addition, the caste like structure of the workplace causes Latino workers to view Korean bosses as cruel and rigid. While the hiring and paying practices of Korean shop owners may reflect some economic necessity, it has detrimental affects on the livelihood of Latino workers. More importantly, it leads to the perception that Korean storeowners are cheap and dishonest.

\section{CREATING THE “OTHER”}

During interviews and ethnographic fieldwork, it became obvious that these interactions were used to create a racial image of the other group. In one particular conversation, a Korean American storeowner told me this story:

I'll tell you what these people are like. Once, I caught this one little kid shoplifting, nothing big, just some candy. When I took him to his mother, she just looked at me in complete shock. Then she asked me what I wanted her to do about it. She asked me why I didn't just take him to the police. Her attitude was, like, I don't care what he does. If you don't like it, take him to the police.

Not surprisingly, this same story was repeated by the majority of the Korean American informants to describe their encounters with Latinos. What perhaps may have been an isolated incident involving one Korean American storeowner has become a sort of an "urban legend" used to generalize all Latinos. In the context of their stores, Korean American storeowners use this characteristic to justify not allowing Latinos to be cashiers. The same informant added:

So you see why they can't be cashiers. I would have 
to watch them all the time. At least with Koreans, I can trust them to be honest. Our people are just not raised that way.

Latinos have also used their experiences with Korean storeowners to create an image of Korean Americans. According to one Latina informant:

I would never work for a Korean. They cheat you, they treat you badly, and expect you to work so hard for so little pay. They are greedy people these Koreans. They are no good.

When asked is she had ever worked for a Korean storeowner, she simply replied:

I don't need to work for them to know. All of my friends who work for Koreans say the same thing.

For both Koreans and Latinos, the interactions within these specific "mediating institutions," in this case the Korean-owned workplaces, have led to the development of stereotypical images for the other. Once developed, these stereotypes were diffused to the larger ethnic community until the grievances of a few became the grievances of the many. As for Korean American storeowners, they came to view Latinos as being unworthy of better job opportunities and thus further limited their ability to enter better paying jobs in the Korean enclave. As for Latinos, they further began to see Korean American storeowners as greedy merchants who would never provide better opportunities for them.

\section{ON A SIMILAR NOTE}

Ironically, the "stories" that Latinos and Korean Americans tell about themselves are strikingly similar, not surprising given the specific historical and contemporary similarities shared by the two groups (Alcoff 2003; Kim 1999; Park 2004). When asked why they immigrated to the United States, one Latino informants told me:

We [he and his wife] came here for our kids. We really wanted to give them a better life, better than what we had in Mexico. It's hard in Mexico, these 
young people, even if they finish school, they have a hard time getting a good job and having a good life. Here, they could go to school and find something good for themselves.

Not surprisingly, a Korean American storeowner said:

We [he and his wife] came here because we wanted a better life for our children. It's hard in Korea. In Korea, they would be under so much pressure and so much stress. And they would need a lot of connections to succeed. Here [in the U.S.], if they study hard, go to a good college, and work hard, they could succeed.

Their worries were similar as well. When asked what their biggest concern was, members of both groups tended to point out the rapid "Americanization" of their children and the loss of "their" culture. As one Latino worker said:

I worry about my daughter. In Mexico, we wouldn't have this kind of problem. Here, she feels like she can wear whatever she wants, go wherever she wants, and do whatever she wants. This isn't right.

Both groups, as Cheng and Espiritu point out (1989) do seem to share and "immigrant ideology" and believed strongly in the "American dream" of hard work leading to success, at least for their children. Both groups viewed America as a place where hard work and perseverance would one day pay off with a better life. As such, both groups saw themselves as having a very strong work ethic. As one Latino worker relayed:

When I first started looking for jobs, like many people from Mexico, I went to the street corner. But many people come to the corner, fifty guys are there and they are looking for an opportunity. Sometimes they don't get an opportunity. I was working with this young guy and he told me he was going to quit, but I talked him out of it. I said 'what are you going to do, you want to go to the street again, to wait one, two, three days to get fifty dollars? This is better.' 
And another said:

It's for sure, I have my work for sure. That's important, for Mexican people to keep working everyday is important. Everyday its hard work, but many people want to do it.

Likewise, Korean merchants also spoke of their diligence:

One time this guy came into the store and said, "You have it easy, nice car, your own business." So I told him, I work 12 hours a day, everyday. I never take a vacation, never go anywhere. If I get sick, I don't make any money. Who has it easy? When I told him that, he looked at me and said, "I guess it's not easy."

For both groups, self descriptions work to promote themselves as the moral superior. If there is any "success," it is due to their hard effort and diligence.

However, Korean American storeowners seem to be aware of their dependence on Latino labor. As one storeowner told me during the California recall election:

We're all very nervous right now. If [Arnold Schwarzenegger] becomes governor, he's going to round up all the Mexicans and ship them off. Most of us can't run our businesses without them, so we're all very nervous. This is a big concern among all the people that I know right now.

Ironically, despite this understanding that they are dependent on Latino labor, members of both groups seem to fail at seeing the similarities. When asked what they felt they had in common with Latinos, one Korean storeowner told me:

We both eat rice, but that's about it. We really don't have much in common with them; we're just from very different cultures.

\section{CONCLUSION}

While the black/Korean conflict has been the subject of 
much scholarly work, relationships between Korean Americans and Latinos has not been the focus of much scholarly literature. Koreans, when discussed in reference to ethnic conflicts, were only incidental to the analysis because of their class positioning as middlemen (Chang 1993; Jo 1992; Min 1989). The explanations advanced so far placed Korean Americans as misunderstood, hard working minorities who were victims of black antagonism arising from historical injustices committed on them. While it may be true that Korean American placement in the new urban environment may have led to their being scapegoated, the fact that they seemed to have come under attack by two different ethnic groups may indicate that they also have a role in shaping ethnic relationships.

Although this paper centers on the role that Koreans play in ethnic conflict, it is important to state that Korean small business owners, particularly those operating small manufacturing operations, hiring cheap Latino laborers and exploiting them is a reflection of the globalization of the world economy. As capitalistic competition continues to take on a more global character, with manufacturers increasingly relying on low cost labor in order to compete effectively in the global market place, manufacturers shift production from the "developed" nations to "developing" nations where labor costs are lower. This shift from a productionbased to a service-based economy in the "developed" nations, however, leads to the displacement of unskilled workers in these regions, with the effect of driving down wages (Ong, Bonacich, and Cheng 1994). Ironically, the in-flow of capital into a region also leads to an out-flow of labor as natives displaced from their land look for opportunities in areas where capital is fleeing (Sassen 1988). In order to stay competitive, Korean American merchants, particularly those who engage in light manufacturing, are almost "forced" into hiring the cheapest possible labor supply. While light manufacturing is the obvious arena where lower labor costs abroad drive down wages at home, it leads to a reduction in wages in other industries as lower wages leads to lower spending in other arenas and a weakening of labor unions (Bonacich 1998; Ong, Bonacich, and Cheng 1994).

Also, this paper should not be taken as an implication that the conflict between Korean American merchants and Latino workers 
"led" to the Los Angeles uprising. By now, we should all be familiar with the actually social, economic, and political factors that led to the now historic event. My discussion about the Los Angeles uprising was simply to point out that there may have been more to the Latino participation in Koreatown, and Korean/Latino conflict by extension, than the simple factor of class.

More importantly, my research allows us to think about possible avenues of further research regarding minority relations in Los Angeles and the rest of the country. It allows us to start asking questions of Korean American merchants as actors in the shaping of ethnic relations rather than as scapegoats or innocent bystanders. This allows us to inquire if other factors may be at play in the formation of ethnic conflicts in multi-ethnic settings.

\section{REFERENCES}

Alcoff, Linda M. 2003. "Latinos/as, Asian Americans, and the BlackWhite Binary." The Journal of Ethic 7: 5-27.

Bergeson, $\mathrm{Al}$ and Max Herman. 1998. "Immigration, Race and

Riot: The 1992 Los Angeles Uprising." American Sociological Review 63: 39-57.

Bergeson, Al. 1996. "Was the L.A. Riots a Backlash Against Recent Immigrants?" Talk given at the University of California, Irvine. Bobo, Lawrence, Camille L. Zubrinsky, and James H. Johnson.

1995. "Work Orientation, Job Discrimination, and Ethnicity: A Focus Group Perspective." Research in the Sociology of Work 5: 45-55.

Bonacich, Edna. 1998. "Organizing Immigrant Workers in the Los Angeles Apparel Industry." Journal of World-Systems Research 4: 10-19.

Bonacich, Edna. 1993. "Asian and Latino Immigrants in the Los Angeles Garment Industry: An Exploration of the Relationship between Capitalism and Racial Oppression," in Immigration and Entrepreneurship. Light, Ivan and Bhachu, Parminder (Eds.). New Brunswick, NJ: Transaction Publishers.

Bonacich, Edna. 1987. "Making it' in America, A Social Evaluation of the Ethics of Immigrant Entrepreneurship." Sociological Perspectives 30: 446-466.

Bonacich, Edna. 1973. "A Theory of Middleman Minorities." 
American Sociological Review 38: 583-594.

Bonacich, Edna. 1972. "A Theory of Ethnic Antagonism: The Split Labor Market." American Sociological Review 37: 547-559.

Chang, Edward. 1993. "Jewish and Korean Merchants in African American Neighborhoods: A Comparative Perspective." Amerasia Journal 19: 5-21.

Cheng, Lucie and Yen Espiritu. 1989. "Korean Businesses in Black and Hispanic Neighborhoods: A Study of Intergroup Relations." Sociological Perspectives 32: 521-534.

Fine, Gary A. and Patricia A. Turner. 2001. Whispers on the Colorline. Berkeley: University of California Press.

Hayes-Bautista, David E., Werner O. Schink, and Maria HayesBautista. 1993. "Latinos and the 1992 Los Angeles Riots: A Behavioral Science Perspective." Hispanic Journal of Behavioral Science 15: 427-448.

Jo, Moon H. 1992. "Korean Merchants in the Black community:

Prejudice Among the Victims of Prejudice." Ethnic and Racial Studies 15: 395-411.

Kim, Claire J. 2000. Bitter Fruit: The Politics of Black-Korean Conflict in New York City. New Haven: Yale University Press.

Kim, David S., and Charles Choy Wong. 1977 "Business Development in Koreatown, Los Angeles." in The Korean Diaspora. Kim, Hyung-Chan (Ed.). Santa Barbara, CA: ABCClio.

Kim, Dae Young. 1999. "Beyond Co-ethnic Solidarity: Mexican and Ecuadorean Employment in Korean-owned Businesses in New York City." Ethnic and Racial Studies 22: 581-605.

Lamphere, Louise, Alex Stepick, and Guillermo Grenier. 1994. New

Comers in The Workplace, Immigrants and the Restructuring of the U.S. Economy. Philadelphia: Temple University Press.

Lee, Jennifer 2002. Civility in the City: Blacks, Jews, and Koreans in Urban America. Cambridge: Harvard University Press.

Light, Ivan, George Sabagh, Mehdi Bozorgmehr, and Claudia DerMartirosian. 1994. "Beyond the Ethnic Enclave Economy." Social Problems 41: 65-79.

Light, Ivan, Har-Chvi Hadas, and Kenneth Kan. 1994. "Black/ Korean conflict in Los Angeles," in Managing Divided Cities. Dunn, Seamus (Ed.). London: Keele University Press. 
Min, Pyong Gap and Andrew Kolodny. 1999. "The Middleman Minority Characteristics of Korean Immigrants in the United States," in Koreans in the Hood: Conflict with African Americans. Kwang Chung Kim (Ed.). Baltimore: Johns Hopkins University Press.

Min, Pyong Gap. 1996. Caught in the Middle: Korean Communities in New York and Los Angeles. Berkeley: University of California Press.

Min, Pyong Gap. 1990. "Problems of Korean Immigrant Entrepreneurs." International Migration Review 24: 436-455. Min, Pyong Gap. 1984. "A Structural Analysis of Korean Business in the United States." Ethnic Groups 6: 1-25.

Ong, Paul, Edna Bonacich, and Lucie Cheng. 1994. "The Political Economy of Capitalist Restructuring and the New Asian Immigration," in The New Asian Immigration in Los Angeles and Global Restructuring. Ong, Bonacich, and Cheng (Eds.). Philadelphia: Temple University Press.

Ong, Paul and Suzanne Hee. 1993. Losses in the Los Angeles Civil Unrest, April 29-May 1, 1992. UCLA Center for Pacific Rim Studies.

Park, Edward J.W. 2004. "Labor Organizing Beyond Race and Nation: The Los Angeles Hilton Case." International Journal of Sociology and Social Policy 24: 137-152.

Park, Edward J.W. and John S.W. Park. 1999. "A New American Dilemma?: Asian Americans and Latinos in Race Theorizing." Journal of Asian American Studies 2: 289-309.

Pastor, Manuel, Lisa Megana, Amalia Cabezas, and Morgan Appel.

1993. Latinos and the Los Angeles Uprising: The Economic Context. Claremont, CA: Thomas Rivera Center.

Sassen, Saskia. 1988. The Mobility of Labor and Capital: A Study in International Investment and Labor Flow. New York: Cambridge University Press.

Skerry, Peter. 1993. Mexican Americans, The Ambivalent Minority. Cambridge, MA: Harvard University Press.

Yoon, In-Jin. 1998. "Who is My Neighbor?: Koreans' Perception of Blacks and Latinos as Employees, Customers, and Neighbors." Development and Society 27: 49-75.

Yoon, In-Jin. 1997. On My Own: Korean Businesses and Race Relations in America. Chicago: University of Chicago Press. 